\author{
Article Type: Review $\quad$ Year: $2020 \quad$ V/I: 6(2) Pages: 26-35 \\ Corresponding Author: Darius Soare Adrian / darius.soare.home@gmail.com \\ DOI: http://dx.doi.org/10.19148/ijhbs. 857331 \\ Citation Information: \\ Soare Adrian, D. (2020). Racism, slavery and personal views on today's political correctness. \\ The International Journal of Human and Behavioral Science, 6(2), 26-35. doi: \\ 10.19148/ijhbs. 857331
}

Received: 01/02/2020

Accepted: 29/12/2020

Published: 30/01/2021

\title{
Racism, Slavery and Personal Views on Today's Political Correctness
}

Darius Soare Adrian, West University of Timişoara, Romania ORCID: https://orcid.org/0000-0003-0051-62611

\begin{abstract}
Racism is the belief that humans are subdivided into distinct hereditary groups that are innately different in their social behavior and mental capacities and that can therefore be ranked as superior or inferior. Racist thinking presumes that differences among groups are innate and not subjective to change. Although beliefs in the superiority and inferiority of different groups have been historically persistent in human societies, the belief that such differences are linked to racial types is a relatively new idea, which did not arise forcefully until the eighteenth century in Europe. Slavery in America started in 1619, when a Dutch ship brought 20 African slaves ashore in the British colony of Jamestown, Virginia. Throughout the 17th century, European settlers in North America turned to African slaves as a cheaper, more plentiful labor source than indentured servants, who were mostly poor Europeans. Though the U.S. Congress outlawed the African slave trade in 1808, the domestic trade flourished, and the slave population in the U.S. nearly tripled over the next 50 years. By 1860 it had reached nearly 4 million, with more than half living in the cotton-producing states of the South. Relations between blacks and whites took on a more confrontational and violent tone during the early 1900s than at any previous time. Nowadays we use political correctness as an instrument that disguise "tolerance", an instrument that is no longer "correct", but abusive.
\end{abstract}

Keywords: Racism, Slavery, Political Correctness, Personal views

\section{Introduction}

Before we begin, to prevent any accusations of racism from both teachers and my fellow colleagues, it is my duty to clarify the correct appellative for the subject I am about to go into. To do so I am going to quote Trey Ellis, an American novelist and an associate professor at the Graduate School of the Arts at Columbia University:

"Since we've been here in America, we've had all this different names for ourselves. Either thrust upon us, or ones we chose: from Colored, to Negro, Afro American, Black And African American. There's the problematic words of Spanish and Portuguese colonialism and their slave trade. So the Blacks were called Negros in both languages. So we were called Blacks. So we use the word "Negro". If you use the word "Colored People", that smacks of the "40s. In the late "50s, and early '60s, civil rights activists on the more radical end were starting to say, "We are not Colored People. We are not Negros. We are Black." They wanted to go all the way in the same way saying, "We're not white". So they really planted a really strong flag for the black power movement, Black Panthers, and black arts movements, and the songs. Jesse Jackson proclaimed one day, in the late '80s, "we are now going to call ourselves African American". And a lot of people just 
thought, "Who are they to decide what we're going to call ourselves now?" And it felt at first like a step backwards, because "Black" really was a big catch-all. But also so powerful. So it really depends on the context. I think "Black" it is just a fantastic, positive word that everybody should feel free to use. By adding "The" to it and the " $S$ " at the end - "The Blacks", it just shows how sort of tone deaf they are. It harks back to kind of an old-fashioned non-PC, look at us as some kind of other to be afraid of."

Racism is the belief that humans are subdivided into distinct hereditary groups that are innately different in their social behavior and mental capacities and that can therefore be ranked as superior or inferior. The presumed superiority of some groups and inferiority of others is subsequently used to legitimize the unequal distribution of society's resources, more specifically, various forms of wealth, prestige and power.

Racist thinking presumes that differences among groups are innate and not subjective to change. Intelligence, temperament, and other primary attitudes, beliefs, and behavioral traits are those viewed as not significantly affected by the social environment. The failures of the groups at the bottom of the social hierarchy are interpreted as a natural outcome of an inferior genetic inheritance rather than of social disadvantages that have accumulated for the group over many generations. In the same manner, the achievements of the group at the top of the social hierarchy are seen as a product of innate superiority, not of favorable social opportunities.

As anthropologist Manning Nash has explained in 1962 (Marger, 2014), racist ideologies depend on three logical confusions:

1. The identification of racial differences with cultural and social differences

2. The assumption that cultural achievement is directly, and chiefly, determined by the racial characteristics of a population.

3. The belief that the physical characteristics of a population limit and define the sorts of culture and society they are able to create or participate in.

\section{The Development of Racism}

Although beliefs in the superiority and inferiority of different groups have been historically persistent in human societies, the belief that such differences are linked to racial types is a relatively new idea, which did not arise forcefully until the eighteenth century in Europe. At that time several political and scientific factors came together that seem to inspire the ideology of racism. The first European peoples begun to have contacts with the peoples of America and Africa, whom were not only culturally different but physically distinct as well. During the age of discovery, starting in the fifteenth century, lands were conquered by Spain, Portugal, England, France and Holland, and white Europeans encountered large number of non-white peoples for the first time. At first, the justification for subjecting these groups to enslavement or to colonial repression, lane not so much in their evident physical differences as much as what was seen as their cultural primitiveness, specifically their non-Christian religions.

Eighteenth-century scholars of various disciplines including medicine, archeology, anthropology, had begun to debate the origin of human species, specifically the question of whether the spices were one or many. Up to this time most have viewed all human types as subdivisions of a single genus. No resolution of that debate came until the publication in 1859 of Darwin's Theory of evolution, the origin of species. Darwin was clear in his explanation that differences among humans were superficial and that they are more general similarities nullified any idea of originally distinct species of races. Although he recognized racial differences, it was left to others to vigorously pursue the measurement of these differences and to attach social meaning to them.

\subsection{African Americans}


Slavery in America started in 1619, when a Dutch ship brought 20 African slaves ashore in the British colony of Jamestown, Virginia. Throughout the 17th century, European settlers in North America turned to African slaves as a cheaper, more plentiful labor source than indentured servants, who were mostly poor Europeans (Marger, 2014).

Though it is impossible to give accurate figures, some historians have estimated that 6 to 7 million black slaves were imported to the New World during the 18th century alone, depriving the African continent of some of its healthiest and best men and women (Marger, 2014). In the 17th and 18th centuries, black slaves worked mainly on the tobacco, rice and indigo plantations of the southern coast, from the Chesapeake Bay colonies of Maryland and Virginia south to Georgia.

But after the Revolutionary War, the new U.S. Constitution tacitly acknowledged the institution of slavery, counting each slave as three-fifths of a person for the purposes of taxation and representation in Congress and guaranteeing the right to repossess any "person held to service or labor" (an obvious euphemism for slavery).

The experience of African Americans is unique among African ethnic minorities. No other group entered the society as involuntary immigrants, and no other group subsequently victimized by two centuries of slavery. Numbering 47,411,470 (nearly 14.6\% of the total American population of 327.7 Million is Black), African Americans are the largest ethnic minority in the United States. They are also the most visible ethnic group (BlackDemographics, 2019).

Blacks first entered American society when they landed in Virginia in 1619. Their legal status, however, was undetermined for at least 40 years. Until the 1660 s, the status of blacks as servants was not essentially different from that of many others, including some whites. Various forms of bondage had been prevalent in all the colonies almost from the founding of the society (Marger, 2014). Perhaps the most common from was voluntary servitude, or indenture, in which a person was bound by contract to serve a master for a certain length of time, usually 4-7 years (Marger, 2014). In exchange, the servant's passage to the colonies was paid. A great number of people, particularly from Scotland and Ireland, entered the country in this manner.

As historian Winthrop Jordan, in 1969, points out, the religious difference between whites and blacks was of greater importance, at least initially, than the physical distinction (Marger, 2014). As Christians, white indentured servants could not be dealt with as nonhumans. Yet the religious factor is not in itself a sufficient explanation for blacks' enslavement because the colonists made no distinction between black nonbelievers and those who had been converted to Christianity; both groups qualified as slaves. Jordan concludes that it was an aggregate of qualities, the total of which set blacks sufficiently apart from others, that made them the most likely candidates for slavery.

Their lack of Christianity and unique physical appearance where vital, but other traits that the English interpreted as savage and bestial "where major components in that sense of difference which provided the mental margin absolutely requisite for placing the European on the deck of the slave ship and the Negro in the hold". The prevalent white images of blacks, explains Jordan, can be traced to the first contacts between the English and Africans in the 16th century. From the first, "Englishmen found blackness in human beings a peculiar and important point of difference". Black skin became a key visible mark for identifying people who were believed to be defective in religion, savage in their behavior and sexually wanton (Marger, 2014).

The American form of slavery that evolved was unique, having had no president in 17th century England (Elkins, 1976). Indeed, it was a system different from any earlier forms of slavery. The Portuguese and Spanish had already enslaved blacks in their colonies and had maintained slaves at home since the early 15th century (Marger, 2014). But the status of slaves in these societies 
differed somewhat from that of their American counterparts. In Brazil and other colonies of Portugal and Spain, slaves maintained certain property and family rights and where often freed. In the American form, however, the slave was essentially an object not to be afforded common human privileges.

The total control of the slave's existence by the plantation master was explicitly legitimized by the slave codes of the various slaveholding states. Slaves lacked virtually all legal rights. They could not own or inherit property, testify in court, hire themselves out, or make contracts. Slave laws clearly stated that marriage between slaves held none of the rights of marriage between free people. As a result, families could be broken up in trade with consideration given to keeping husband, wife, and children intact as a single unit. Finally, laws forbade teaching slaves to read and write.

Most slaves lived on large plantations or small farms; many masters owned fewer than 50 slaves. Slave owners sought to make their slaves completely dependent on them, and a system of restrictive codes governed life among slaves. They were usually prohibited from learning to read and write, and their behavior and movement was restricted.

Many masters took sexual liberties with slave women, and rewarded obedient slave behavior with favors, while rebellious slaves were brutally punished. A strict hierarchy among slaves helped keep them divided and less likely to organize against their masters. Slave marriages had no legal basis, but slaves did marry and raise large families; most slave owners encouraged this practice, but nonetheless did not usually hesitate to divide slave families by sale or removal (David, 1984).

Enforcement and interpretation of the slave laws were left almost entirely to the master, not the courts. With such wide discretion, utter cruelty was not uncommon, but it was felt that brutal treatment would be controlled through public opinion, by the master's sense of decency, and above all by economic interest. Slaves, representing a significant financial investment, would not be physically or emotionally abused to the point of incapacity. Historians Robert Fogel and Stanley Engerman explain, for example, that although slave marriages were not legally recognized, masters nonetheless encouraged their slaves to marry and to establish families in order to ensure an atmosphere of stability (Marger, 2014).

In the late 18th century, with the land used to grow tobacco nearly exhausted, the South faced an economic crisis, and the continued growth of slavery in America seemed in doubt.

Around the same time, the mechanization of the textile industry in England led to a huge demand for American cotton, a southern crop whose production was unfortunately limited by the difficulty of removing the seeds from raw cotton fibers by hand. But in 1793, a young Yankee schoolteacher named Eli Whitney invented the cotton gin, a simple mechanized device that efficiently removed the seeds. His device was widely copied, and within a few years the South would transition from the large-scale production of tobacco to that of cotton, a switch that reinforced the region's dependence on slave labor (Marger, 2014).

The slave revolt that most terrified white slaveholders was that led by Nat Turner in Southampton County, Virginia, in August 1831. Turner's group, which eventually numbered around 75 blacks, murdered some 60 whites in two days before armed resistance from local white forces overwhelmed them. Supporters of slavery pointed to Turner's rebellion as evidence that blacks were inherently inferior barbarians requiring an institution such as slavery to discipline them, and fears of similar insurrections led many southern states to further strengthen their slave codes in order to limit the education, movement and assembly of slaves (Breen, 2015). 
From the 1830s to the 1860 s, the movement to abolish slavery in America gained strength, led by free blacks such as Frederick Douglass and white supporters such as William Lloyd Garrison, founder of the radical newspaper The Liberator, and Harriet Beecher Stowe, who published the bestselling antislavery novel Uncle Tom's Cabin. While many abolitionists based their activism on the belief that slaveholding was a sin, others were more inclined to the non-religious "freelabor" argument, which held that slaveholding was regressive, inefficient, and made little economic sense. Free blacks and other antislavery northerners had begun helping fugitive slaves escape from southern plantations to the North via a loose network of safe houses as early as the 1780s. This practice, known as the Underground Railroad, gained real momentum in the 1830s and although estimates vary widely, it may have helped anywhere from 40,000 to 100,000 slaves reach freedom (Marger, 2014).

Though the U.S. Congress outlawed the African slave trade in 1808, the domestic trade flourished, and the slave population in the U.S. nearly tripled over the next 50 years. By 1860 it had reached nearly 4 million, with more than half living in the cotton-producing states of the South. Relations between blacks and whites took on a more confrontational and violent tone during the early 1900s than at any previous time. This situation was brought about by demographic and economic changes in the society that placed the two groups in direct competition (Marger, 2014).

Industrial expansion in the North created an increased demand for labor, and with the cutoff of immigration from Europe, black people from the South began to fill these places. If jobs were the key "pull" factor impelling black out-migration from the South, the declining cotton economy and the continued enforcement of Jim Crow were the chief "push" factors. The demographic changes involving the black populace were profound. In 1910, almost 90 percent of blacks were living in the South (Marger, 2014), but eighty years later, little more than half remained there. Streams of black people from the South to the North and West reached epic proportions from 1940 to 1970 , with almost 1.5 million leaving in each of these three decades. Moreover, this migration was almost wholly to the cities, making black people an increasingly urbanized population.

From the late 1950s to about 1964, nonviolent protest and civil disobedience were the movement's chief tactics. The basic idea was that individuals had a moral duty to disobey the law when it was clearly unjust. This was a strategy that had been applied many times historically in a variety of social settings, its most notable success occurring in the 1940s in India, where Mahatma Gandhi led the movement for independence from Britain. The technique was to actively oppose the law but in a peaceful fashion. The proponents of nonviolent protest, Martin Luther King, Jr., (Marger, 2014) in particular, emphasized that it was necessary to win over the opposition through friendship and understanding, not through defeat or humiliation.

A pivotal year was 1963 (Marger, 2014), when several key events occurred. Police brutally suppressed black demonstrators in Birmingham, Alabama, a Birmingham church was firebombed, killing four black children, and National Guardsmen were used to carry out the courtordered desegregation of the University of Alabama. These events were given prominent media attention and galvanized public and governmental support for black civil rights. This supportive mood climaxed with the march on Washington of over 200.000 people in August of that year. One year later, the most comprehensive civil rights measure since the Civil War (1861-1865) was enacted. Prohibiting discrimination in voting, public facilities, schools, courts and employment. And in 1965, the Voting Rights Act was passed, ending the systematic disenfranchisement of southern blacks.

By the early 1970s, the "Second Reconstruction" has ended, and black people began to take stock of their advances and failures of the previous two decades. No longer could state and local 
ordinances prevent black people from entrance into hotels, theaters, restaurants, trains, buses, waiting rooms and all other public facilities previously reserved for whites.

\subsection{The Legacy of Slavery}

The 13th Amendment, adopted on December 18, 1865, officially abolished slavery, but freed blacks' status in the post-war South remained precarious, and significant challenges awaited during the Reconstruction period.

Former slaves received the rights of citizenship and the "equal protection" of the Constitution in the 14th Amendment and the right to vote in the 15th Amendment, but these provisions of the Constitution were often ignored or violated, and it was difficult for former slaves to gain a foothold in the post-war economy thanks to restrictive black codes and regressive contractual arrangements such as sharecropping.

Despite seeing an unprecedented degree of black participation in American political life, Reconstruction was ultimately frustrating for African Americans, and the rebirth of white supremacy —including the rise of racist organizations such as the Ku Klux Klan (KKK) - had triumphed in the South by 1877.

Almost a century later, resistance to the lingering racism and discrimination in America that began during the slavery era would lead to the civil rights movement of the 1960s, which would achieve the greatest political and social gains for blacks since Reconstruction.

\subsection{Rosa Parks}

On December 1, 1955, a 42-year-old woman named Rosa Parks found a seat on a Montgomery, Alabama bus after work. Segregation laws at the time stated blacks must sit in designated seats at the back of the bus, and Parks had complied. When a white man got on the bus and could not find a seat in the white section at the front of the bus, the bus driver instructed Parks and three other blacks to give up their seats. Parks refused and was arrested.

As word of her arrest sparked outrage and support, Parks unwittingly became the "mother of the modern-day civil rights movement". Black community leaders formed the Montgomery Improvement Association (MIA) led by Baptist minister Martin Luther King Jr., a role which would place him front and center in the fight for civil rights. Parks' courage incited the MIA to stage a boycott of the Montgomery bus system. The boycott lasted 381 days. On November 14, 1956, the Supreme Court ruled segregated seating was unconstitutional (Theoharis, 2015).

\subsection{Civil Rights Leaders Assassinated}

The civil rights movement had tragic consequences for two of its leaders in the late 1960s. On February 21, 1965, former Nation of Islam leader and Organization of Afro-American Unity founder Malcolm X was assassinated at a rally. On April 4, 1968, civil rights leader and Nobel Peace Prize recipient Martin Luther King, Jr. was assassinated on his hotel room's balcony. Emotionally charged looting and riots followed, putting even more pressure on the Johnson administration to push through additional civil rights laws (Nwagbaraocha, 2019).

\section{Slavery in Ancient Rome}

Most slaves in ancient Rome were war prisoners, and other ways you could become one were to have been sold by your parents for money; to be an orphan or to be born into a family of slaves. In order to get into the possession of some slaves, all you had to do was buy them. They were naked and exposed to the crowd of buyers. Wealthy people usually owned a lot of slaves who had to fulfill each master's task, and most did not receive money for the jobs they were being subjected to (For a slavish slave, gathering a sum of money could mean buying one's own freedom, we can say that freedom was the Roman dream). 
In ancient Rome, slaves became essential, the city and free families would not have been able to survive without their work. In this case we can say that without a lower class there could not be a higher class. The need to have slaves was very high because the free families could not take care of their own needs, they could not feed or dress without their help.

The slaves were considered to be simply objects and nothing more. In such a world you could still survive if you had an education, if you knew how to cook or if you were born with a very pleasant and appealing physical appearance, man or woman. If you had an education and you knew the Greek language, your purchase price rose immediately. The first masters of Roman slaves used their staff as "speaking objects" and relied on their fear of punishments such as whipping and chaining as a sovereign way of causing them to work. The food and the clothes of the slaves, although quantitatively enough, were of the worst quality, the bedrooms were often dug under the ground. Their work, besides being endless, was also monotonous, they had no right to family life, and their chances of redeeming their freedom from "peculium" or pocket money were exceptionally low. Under these circumstances, slaves were increasingly thinking of revolting, and even if Italy managed to avoid a massive slavery war in the 2 nd century BC (Bradley, 1994), smaller revolts occurred.

The main weapon of dissatisfied slaves was passive resistance or insubordination. They rebuked the masters by hijacking their property or doing their work in a careless way; as soon as the team leader was not watching them, they slowed the pace of work. It often happens that property managers conspire themselves with their subordinates to reduce the productivity of work to a minimum. In the best case, slave labor was profitable as long as their price remained low.

\subsection{Slaves Sexual Abuse in Ancient Rome}

In ancient Rome, there were no different terms for heterosexuality or homosexuality, sexuality being defined by passive or active behavior shown during sexual intercourse. Free citizens, especially the rich, were entitled to dispose of personal sins in any way without being held accountable, the children being considered "delicious" or "puer delicatus", true sexual truffles (Bradley, 1994). Roman citizens could exploit their slaves, regardless of the circumstances in which they had come to the world or their age. A free citizen could rape, torture or abuse his property in any way without being held accountable. The slaves did not have any civil protection or any right over their own body. The body of a slave was at the disposal of the master, and that meant he could use it to satisfy his sexual appetites. There is a law about which little information has been stored, called Lex Scantinia, which, however, protects free citizens from sexual abuse or rape. In particular, sex crimes (stuprum) against a minor male (ingenuus or praetextatus) were penalized (Bradley, 1994).

Also, the law mentions the punishment of men, especially free citizens of good condition, who willingly accepted to play a passive role in sexual intercourse with another man, the law was designed to prevent possible sexual abuse among free citizens. However, the law was not respected. On a case-by-case basis, abuse of a free minor, for example, was not punished by death sentence, but huge grievances were often paid to resolve the matter.

\subsection{Antinous, the Beautiful Slave Loved by the Emperor Hadrian}

Sexual slaves were often envied by the other slaves, being well treated as long as they were in the graces of their masters and did everything they were told without the shadow of opposition. Famous is the relationship of Emperor Hadrian with a young slave, the beautiful Antinous, a boy playing the role of a loved one. Antinous died drowning during a walk on the Nile, and historians assume that his killing was, in fact, a sacrifice to the gods. In memory of his beloved slave, Hadrian had founded the city of Antinoopolis in Egypt, and Antinous's name would have been deified, honor, which would normally be reserved for members of the royal family (Bradley, 1994). 


\section{Greece}

The main sources of slavery are war, birth, piracy, and private law. The first source of slaves is war. Slavery first appears - however paradoxical it may be - as a breakthrough. During the archaic period, primitive Greek tribes did not have slaves. Prisoners taken from tribal wars were killed. Slavery occurs when people prefer to let prisoners alive, not as a sign of human decency, and neither because they have earned it through their work or by selling them for money.

In Greek society, most of the slaves are former prisoners of war. The defeated warrior becomes the slave of victor and remains in his possession if his family cannot pay a proper redemption. Those who cannot redeem themselves are sold. After an assault, people in a conquered city are generally passed through the sword's edge. Women and children are divided between winners and kept or sold as slaves. In this situation are Hecuba, Andromaca, Casandra.

Another source of slavery is piracy, which also procures many slaves. From the barbarian countries, located in the northern Balkans or in southern Russia, there were excellent slaves for sale brought by those involved in piracy. This practice is found even in some Greek lands (in Thessaly, in Etolia, for example), where state and police authority is not so strong to prevent poaching of human hunters. The Athenian historian and general Thucydides concluded: "The Athenians kill all Melians able to carry their weapons and take the women and children into slavery" (Bradley, 1994). The sources of slaves are quite numerous even during peacetime. The child of a slave woman is a slave being the property of her mother's master. But most of the time he is exposed at the roadside and dies. The master believes it is too costly to let this child live, and so it won't feed him until he is able to work.

The proletarian who cannot find work and is hungry can sell himself as a slave to a master who will give him food. Private law is also a source of recruitment for slavery. Let us not forget that in most of the Greek states the insolvent borrower can be sold as a slave and the price obtained from the sale was given to the creditor. Athens is the only Greek city, according to information, which forbade slavery for debt through the laws of Solon. Slavery could also be acquired through other sources. Athenaeus the Greek rhetorician and grammarian writes that a physician, Menecrates of Syracuse, who does not accept taking care of some of the sick that are in a desperate condition, except under one condition: if they were committed to becoming his slaves if they healed (Bradley, 1994).

\section{Personal Views on Political Correctness}

I believe in the importance of human interaction and ultimately, I am against all the racism, misogyny, homophobia, xenophobia, bullying and any kind of intolerance towards our brothers and sisters. That is surely something that we all have in common or at least we should have.

I have always kept my opinions to myself during certain debates and I have always tried not to be bothered by people who do not use scientific knowledge in certain domains. But an event that took place a while ago has brought me to the point where I cannot stand hearing anymore people talking about social issues using something that can be described as Post-Truth.

Post-Truth (Oxford, 2016) declared word of the year by Oxford Dictionaries, it is described as: "Relating to or denoting circumstances in which objective facts are less influential in shaping public opinion than appeals to emotion and personal belief." What does it mean? It means that our society prefers emotionally charged speeches over factual ones. I believe that this represents a sort of compromise, a compromise that would not help us in the long run.

Returning to my latest experience, I was called a racist meanwhile trying to explain why political correctness is going way too far with changing white historical personalities with black ones. I 
know that this might sound racist to some or to most people nowadays, but I will do my best explaining why it is not offensive in any possible way.

The conversation started with me asking: "Do you find changing white historical personalities with black ones, alright? Given the fact that in a film that describes Mary Queen of Scots (2018), Thomas Randolph was depicted as being black when he was not". Thomas Randolph (15231590) was an English ambassador serving Elizabeth I of England. Most of his professional life he spent in Scotland at the courts of Mary, Queen of Scots, and her son James VI (Michel, 1992).

First, I was told that I did have a problem with black people and then I was called a racist. What came after was a failed counter argument that was supposed to prove how racist I am. My opponent recalled: "There was a movie made by Hollywood in the " 80 s where it was depicted the first black person in a position of a judge".

I did my homework and after close internet research Marshall was the only production that was close to what my opponent was saying. Marshall is a 2017 American biographical legal drama film where the first African American Supreme Court Justice focuses on one of the first cases of his career, the State of Connecticut v. Joseph Spell.

My accuser was wrong about pretty much everything. The trial of Joseph Spell, State of Connecticut v. Joseph Spell, was a 1940 legal case in which an African American chauffeur was accused of raping the wealthy white woman who was his boss, Eleanor Strubing. As well when I was talking about the way the events were depicted in the film Mary Queen of Scots, he tried to point out that "history is written by the winners", which is true, and by that "history is relative".

When we say that something is relative, we are giving the chance to our opponent to point out that everything is relative after all. Although the persona of Thomas Randolph is not something that is relative. He was an ambassador which is described in tens of letters and historical acts. We could simply say that color does not matter and end it all. And it does not matter. The color of your skin does not make you any less valid than you already are. But things do not work this way, history as tragic, racist, violent and as sad as might have been, it simply describes what the times were back then. There were people of color in England during that time. According to the U.K. national archives, Elizabeth I would have employed black servants and musicians, and even had a black chambermaid, though seeing a person of color as high up as Lord Randolph would have been improbable. The director of the movie, Josie Rourke, said:

"I was really clear, I would not direct an all-white period drama", Rourke said. "Adrian, who plays, Lord Randolph, grew up 40 miles from the birthplace of William Shakespeare; he is one of our eminent Shakespearean actors. I needed to cast an ambassador who could move between the two courts and help this make sense. I don't understand why you wouldn't cast him."

It is my duty to reiterate a previous affirmation of mine. History as tragic, racist, violent and as sad as might've been, it simply describes what the times were back then. By doing that we are simply changing history. On the social side, if there would have been a black ambassador in a country such as the United Kingdom, there would have followed other high political positions for black people. Finally, this might have changed the whole history of our humankind and surely most of the negative racial historic events would not have taken place.

What looks as a minor and insignificant change in a movie, it is a wrong portrayal of history of both black peoples and human events. There is also a big difference between the $16^{\text {th }}$ and $20^{\text {th }}$ century mindset. Including black people in the film industry in the $20^{\text {th }}$ century was necessary because most of society was ready to embrace this change, but this could not happen before in history due to the society's mindset. 
In my opinion, political correctness is not the way. Political correctness is very obsessed with being right and forgets about the necessity of effectiveness. And as for slavery, all human beings were slaves at some point. It is common knowledge. It is important how you are treated. Basic human rights are not a direct result of political correctness, what it is really all about is basic human compassion and respect.

\section{References}

BlackDemographics. (2019, 10 8). The African American Population. Retrieved from https://blackdemographics.com/

Bradley, K. (1994). Slavery and Society at Rome. United Kingdom: Cambridge University Press.

Breen, P. H. (2015). The Land Shall Be Deluged in Blood: A New History of the Nat Turner Revolt. United Kingdom: Oxford University Press.

David, B. (1984). Slavery and Human Progress. United Kingdom: Oxford University Press.

Elkins, S. (1976). Slavery: A Problem in American Institutional and Intellectual Life. Chicago:

University of Chicago Press.

Marger, M. N. (2014). Race and ethnic relations - American and global perspectives. Michigan: Cengage Learning, Inc.

Michel, D. (1992). Elisabeta I. București: Editura Artemis.

Nwagbaraocha, J. O. (2019). Evolution of an Educator: From Nigerian Student to American College Administrator. FriesenPress.

Oxford. (2016). Oxford Learner's Dictionaries. Retrieved from https://www.oxfordlearnersdictionaries.com/definition/english/post-truth

Theoharis, J. (2015). "How History Got Rosa Parks Wrong". Washington Post. 